\title{
PENYULUHAN PENTINGNYA ASI EKSKLUSIF DI POSYANDU MAWAR PEKON SIDOMULYO WILAYAH KERJA PUSKESMAS PAGAR DEWA LAMPUNG BARAT TAHUN 2017
}

\author{
Aryanti Wardiyah ${ }^{1}$, Riska Wandini ${ }^{2}$, Suryani ${ }^{3}$ \\ ${ }^{1}$ Akademi Keperawatan Malahayati, Bandar Lampung \\ 2 Fakultas Kedokteran, Universitas Malahayati, Lampung \\ ${ }^{3}$ Puskesmas Pagar Dewa, Lampung Barat
}

Email: aryanti@malahayati.ac.id; riska.wandini@gmail.com; suryani@gmail.com

\begin{abstract}
ABSTRAK
Masalah gizi yang paling utama pada saat ini, di Indonesia adalah kurang kalori dan protein. Hal ini banyak ditemukan pada bayi dan anak. Berbagai alasan dikemukakan oleh ibu-ibu mengapa keliru dalam pemanfaatan ASI secara eksklusif kepada bayinya, antara lain adalah produksi ASI kurang, keinginan untuk disebut modern dan pengaruh iklan pengganti ASI dan anggapan bahwa semua orang sudah memiliki pengetahuan tentang ASI. Tujuan kegiatan diharapkan warga dapat mengerti tentang pentingnya ASI eksklusif pada bayi.Kegiatan ini telah dilaksankan pada hari Jumat tanggal 15 Desember 2017. Adapun kegiatan yang dilakukan berupa penyuluhan kepada ibu-ibu tentang pentingnya Asi ekslusif di Posyandu Mawar Pekon Sidomulyo Lampung Barat dengan metode penyuluhan menggunakan leaflet. Terdapat pengaruh signifikan pada pengetahuan ibu sebelum dan sesudah penyuluhan asi eksklusif. Dengan demikian, pemberian edukasi dapat memberikan peningkatan pengetahuan, khususnya yang berkaitan dengan ASI Eksklusif.
\end{abstract}

Kata Kunci: asi eksklusif, tingkat pengetahuan, penyuluhan

\begin{abstract}
The most important nutritional problem in Indonesia is less calories and protein. It is commonly found in infants and children. Various reasons on mothers who misunderstanding about exclusive breastfeeding to their babies, including the production, the desire to be modern mother and the influence of substitute advertising milk and the assumption that everyone already has knowledge about breastfeeding. The purpose of the activity is expected to be able to understand about the importance of exclusive breastfeeding in babies. This activity was carried out on Friday, December 15, 2017. The activities carried out in the form of counseling to mothers about the importance of exclusive Breastfeeding in Posyandu Mawar Pekon Sidomulyo Lampung Barat using leaflets. There was a significant influence on mother's knowledge before and after exclusive counseling. Thus, the provision of education can provide increased knowledge, particularly those related to exclusive breastfeeding.
\end{abstract}

Keywords: Exclusive Breastfeeding, Level of Knowledge, Counseling 


\section{PENDAHULUAN}

Kesehatan merupakan salah satu aspek dari kehidupan masyarakat mutu hidup, produktifitas tenaga kerja, angka kesakitan dan kematian yang tinggi pada bayi dan anak-anak, menurunnya daya kerja fisik serta terganggunya perkembangan mental adalah akibat langsung atau tidak langsung dari masalah gizi kurang.Terjadinya kerawanan gizi pada bayi disebabkan karena selain makanan yang kurang juga karena Air Susu Ibu (ASI) banyak diganti dengan susu botol dengan cara dan jumlah yang tidak memenuhi kebutuhan. Hal ini pertanda adanya perubahan sosial dan budaya yang negatif dipandang dari segi gizi (Kemenkes RI, 2017).

ASI sebagai makanan yang terbaik bagi bayidan tidak perlu diragukan lagi, namun akhir-akhir ini sangat disayangkan banyak diantara ibu-ibu meyusui melupakan keuntungan menyusui. Selama ini dengan membiarkan bayi terbiasa menyusu dari alat pengganti, padahal hanya sedikit bayi yang sebenarnya menggunakan susu botol atau susu formula. Kalau hal yang demikian terus berlangsung, tentunya hal ini merupakan ancaman yang serius terhadap upaya pelestarian dari peningkatan penggunaan ASI. Salah satu factor yang berpengaruh pada pemberian susu formula pada bayi adalah dukungan keluarga (Nurmawati, Nugraheni dan Kartini, 2015).

Di Indonesia masalah gizi buruk hingga saat ini masih belum teratasi. Salah satu masalah gizi yang paling utama pada saat ini, di Indonesia adalah kurang kalori dan protein. Hal ini banyak ditemukan pada bayi dan anak yang masih kecil. Keadaan ini karena anak dan bayi merupakan golongan rentan. Selain itu banyak ibu yang melahirkan bayi prematur yaitu bayi dengan berat badan rendah karena tidak sesuai dengan usia kelahirannya. Bayi dengan berat badan rendah memiliki resiko besar terkena infeksi dan lebih memperlukan ASI lebih besar dibanding bayi dengan berat badang normal (Azwar, 2004).

Berbagai alasan dikemukakan oleh ibu-ibu mengapa keliru dalam pemanfaatan ASI secara Eksklusif kepada bayinya, antara lain adalah produksi ASI kurang, kesulitan bayi dalam menghisap, keadaan puting susu ibu yang tidak menunjang, ibu bekerja, keinginan untuk disebut modern dan pengaruh iklan/promosi pengganti ASI dan tidak kalah pentingnya adalah anggapan bahwa semua orang sudah memiliki pengetahuan tentang manfaat ASI. Maka tim pengusul tertarik untuk melaksanakan penyuluhan tentang Asi Eksklusif di Posyandu Mawar Pekon Sidomulyo Pagar Dewa lampung Barat.

Tujuan umumnya yaitu diharapkan warga dapat mengerti tentang pentingnya ASI eksklusif pada bayi dan tujuan khusus nya yaitu dapat menjelaskan tentang ASI eksklusif, dapat menjelaskan tentang kandungan ASI, dapat menjelaskan manfaat pemberian ASI eksklusif, dapat menjelaskan hambatan menyusui secara eksklusif pada ibu. 


\section{MASALAH}

Warga masyarakat di wilayah kerja Puskesmas Pagar Dewa terdiri dari berbagai jenis suku dan tingkat pendidikan,. Pemahaman yang kurang tepat mengenai ASI eksklusif menjadi salah satu alasan dilakukannya kegiatan pengabdian ini. Adanya anggapan bahwa seorang ibu tentang menyusui, produksi ASI kurang, kesulitan bayi dalam menghisap, keadaan puting susu ibu yang tidak menunjang, ibu bekerja, keinginan untuk disebut modern. Hal ini diperberat dengan adanya iklan susu formula di televisi yang dapat memberikan kecendrungan seorang ibu malas menyusui. Maka tim pengusul tertarik untuk melaksanakan penyuluhan tentang Asi Eksklusif di Posyandu Mawar Pekon Sidomulyo Pagar Dewa lampung Barat. Target kegiatan ini adalah terpaparnya masyarakat khususnya ibu-ibu yang memiliki balita di wilayah kerja Puskesmas Pagar Dewa tentang asi eksklusif. Berikut peta lokasi Puskesmas Pagar Dewa.

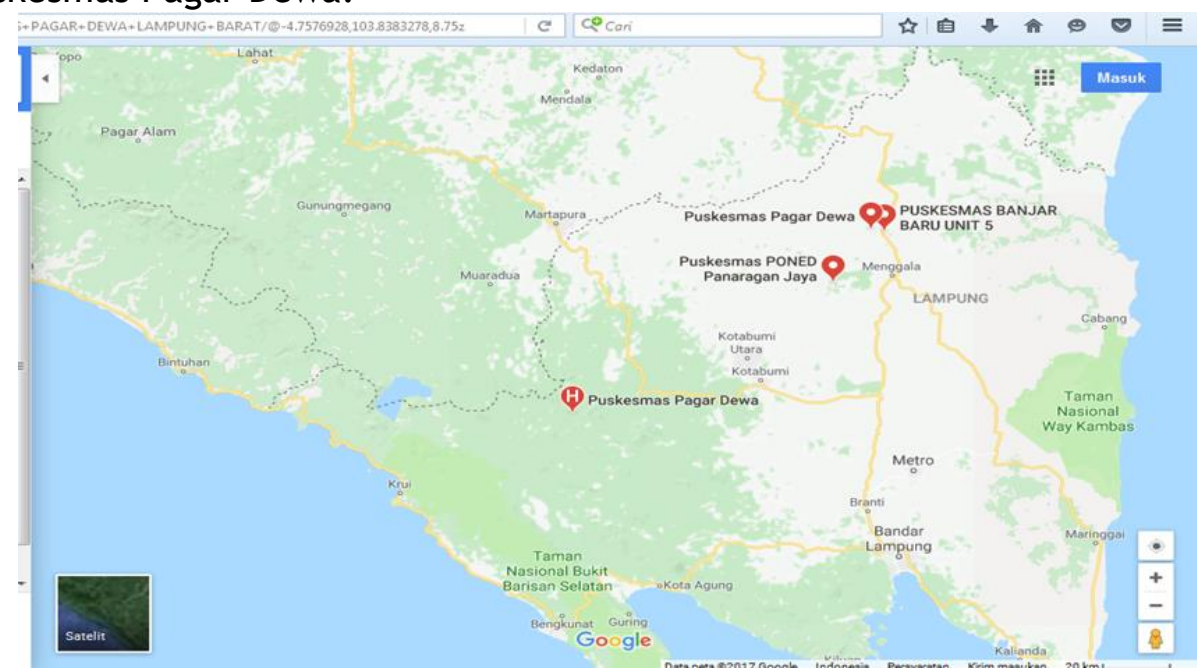

Gambar 2.1. Peta lokasi Puskesmas Pagar Dewa

\section{METODE}

Subyek dalam kegiatan pengabdian ini adalah ibu yang memiliki bayi dan berada di Pekon Sidomulyo Pagar Dewa Lampung Barat. Pada tahap awal dilakukan pengukuran tingkat pengetahuan yang berkaitan dengan asi ekslusif. Pertanyaan yang diberikan seputar definisi, manfaat, waktu pemberian. Soal soal tersebut berbentuk pertanyaan terbuka.

Setelah dilakukan pre test, kegiatan selanjutnya adalah penyuluhan tentang asi eksklusif. Materi akan dijelaskan oleh narasumber dengan menggunakan media power point yang menarik, dan juga leaflet tentang asi eksklusif. Setelah penyuluhan selesai, subyek kegiatan diberikan pertanyaan lagi (post test) dengan pertanyaan yang sama. 


\section{HASIL \& PEMBAHASAN}

Penyuluhan tentang asi eksklusif di wilayah kerja Puskesmas Pagar Dewa berjalan dengan lancar. Peserta yang hadir sekitar 30 ibu ibu dengan membawa anaknya. Berikut gambar pelaksanaan penyuluhan:

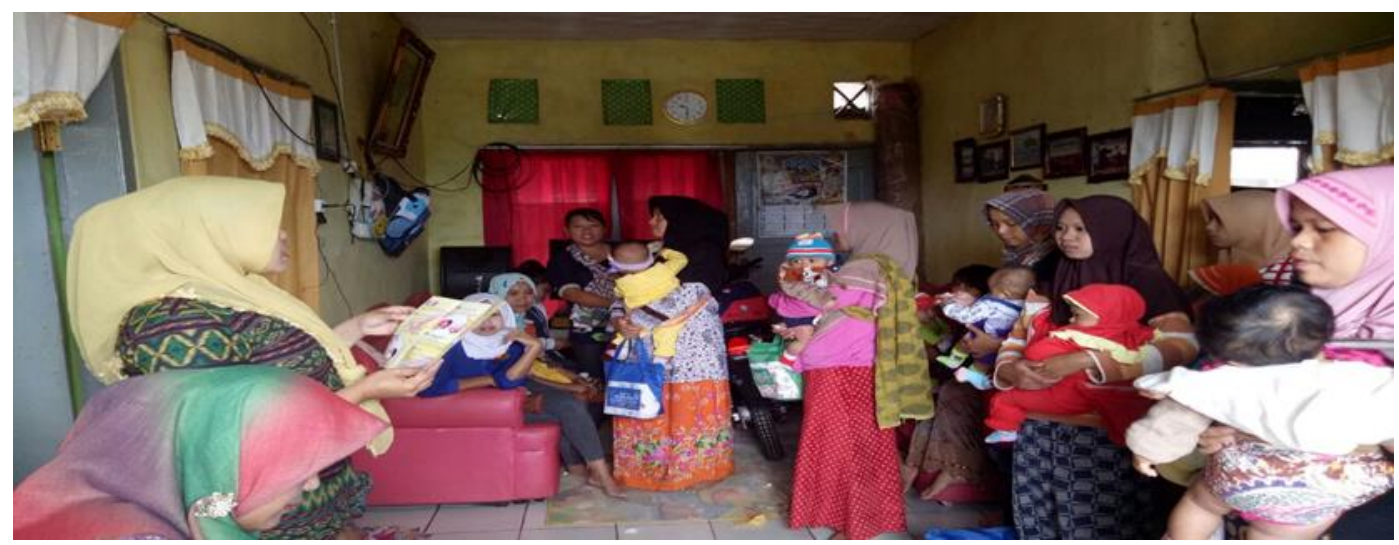

Gambar 4.1. Penyuluhan tentang Asi eksklusif

Pengetahuan subyek (ibu yang memiliki bayi) meningkat, yang awalnya tidak mengetahui tentang manfaat asi eksklusif menjadi tahu. Terdapat $80 \%$ ibu yang mengalami peningkatan pengetahuan tentang asi eksklusif. Rerata peningkatan sebelum dan sesudah dilakukan penyuluhan pada kisaran angka 45\%. Hal ini masih tergolong cukup baik. Adanya variasi dari karakteristik subyek menjadi salah satu faktor yang mempengaruhi pencapaian rerata peningkatan pengetahuan.

Kegiatan pengabdian kepada masyarakat awalnya mengaami hambatan. Hal ini terjadi karena tidak semua subyek tertarik pada bidang kesehatan, adanya kesibukan lain dari subyek kegiatan misalnya subyek tidak konsentrasi saat diadakan penyuluhan. Namun, dengan pendekatan yang terus menerus dan bersahabat, pada akhirnya hambatan tersebut dapat diatasi.

\section{SIMPULAN}

Kesimpulan yang dapat diambil dari uraian kegiatan pengabdian kepada masyarakat di wilayah kerja Puskesmas Pagar Dewa Lampung Barat antara lain. Pertama: adanya peningkatan pengetahuan tentang asi eksklusif pada subyek kegiatan dengan rerata peningkatan sebesar $45 \%$. 


\section{DAFTAR PUSTAKA}

Azwar, A. (2004). Kecenderungan masalah gizi dan tantangan di masa datang. Jakarta: Kemenkes RI.

Arifin,M.S. (2004). Faktor-faktor yang mempengaruhi pemberian ASI oleh ibu Melahirkan. Medan: USU digital library.

Kemenkes RI. (2017). Pedoman Umum Pemberian Makanan Pendamping Air Susu Ibu . http://gizi.depkes.go.id/asi/pedoman\%20MP-ASI\%20Lokal.pdf.

Elza,Y.(2008).Dukung ibu untuk meraih emas. Ditelusuri dari http://www.promosikesehatan.com dibuka pada 25 Oktober 2010.

Erlina,Y.(2008). Fakto-Faktor Yang Mempengaruhi Rawat Gabung. Dibuka tanggal 25 Agustus 2010, Ditelusuri dari http://kuliahbidan.wordpress.com.

Nurmawati,A, Nugraheni \& Kartini (2015).Faktor determinan Pemberian Susu Formula pada Bayi Usia 0-6 Bulan .Fakultas Kesehatan Masyarakat Universitas Diponegoro: Semarang.

Prasetyono, Dwi Sunar.(2009). Buku Pintar ASI Ekslusif. Yogyakarta : Diva Press.

Roesli, Utami. (2000). Mengenal ASI Eksklusif. Jakarta : Trubus Agiwidya.

Soetjiningsih. (1997). ASI Petunjuk V Tenaga Kesehatan. Jakarta : EGC. 